\section{THE CONSERVATION OF CULTURAL HERITAGE ALONG AMPHAWA CANAL, SAMUT SONGKHRAM PROVINCE}

\section{Wannasilpa Peerapun, Siriwan Silaphacharanan, and Vira Sachakul ${ }^{1}$}

\section{Abstract}

The Amphawa community houses the birth place of King Rama II. Nowadays this community is still water-based and one can see Thai-styled and row houses, canal-side walkways and ladders leading down to the canal. Against this backdrop are coconut plantations and mixed orchards of pomelo, lychee, etc. Amphawa is also rich in Thai culture featuring mural paintings, traditional dance and music and architecture. Water-based ways of life are very much alive as evidenced by water traffic. The objective of the project is to modify and apply the SAVE and CHIP techniques devised by the Danish Government as part of Cultural Heritage Conservation, awareness-raising campaign and demonstration of conservation campaign of traditional buildings ranging from government buildings, Thai-styled and contemporary houses and row houses to the rehabilitation of a canal landscape. As a result, local people are better aware of the advantages of cultural heritage conservation while the project enhances the preparedness of the community to accommodate ecological tourism. Finally, the experience gained from this project can also be applied to other areas of Thailand.

\section{Keywords}

Cultural heritage environment, conservation, awareness raising, demonstration project

\section{Introduction}

The Faculty of Architecture, Chulalongkorn University has undertaken a study and pertinent related actions in the Amphawa Canal area since 1991 involving the following : 1) The Study and Formulation of a Master Plan and an Action Plan for the Conservation and Development of the Environment along Rivers, Canals and Ditches in the Western Region of Thailand, financed by the Office of Environmental Policy and Planning (OEPP) 2) The Pilot Project for the Improvement and Revitalization of the Environment of Amphawa Canal, financed by the Environmental Fund, 3) The Architectural Student Volunteer Project financed by the Faculty of Architecture and 4) Thailand Cultural Environment Project (TCEP), financed by the OEPP and the Danish Government (DANIDA). The following article will be confined to the experience gained from the implementation of the conservation of cultural heritage and the environment under the TCEP, undertaken from 20022005.

\footnotetext{
${ }^{1}$ Associate Professors, Department of Urban and Regional Planning, Faculty of Architecture, Chulalongkorn University, Thailand.
} 


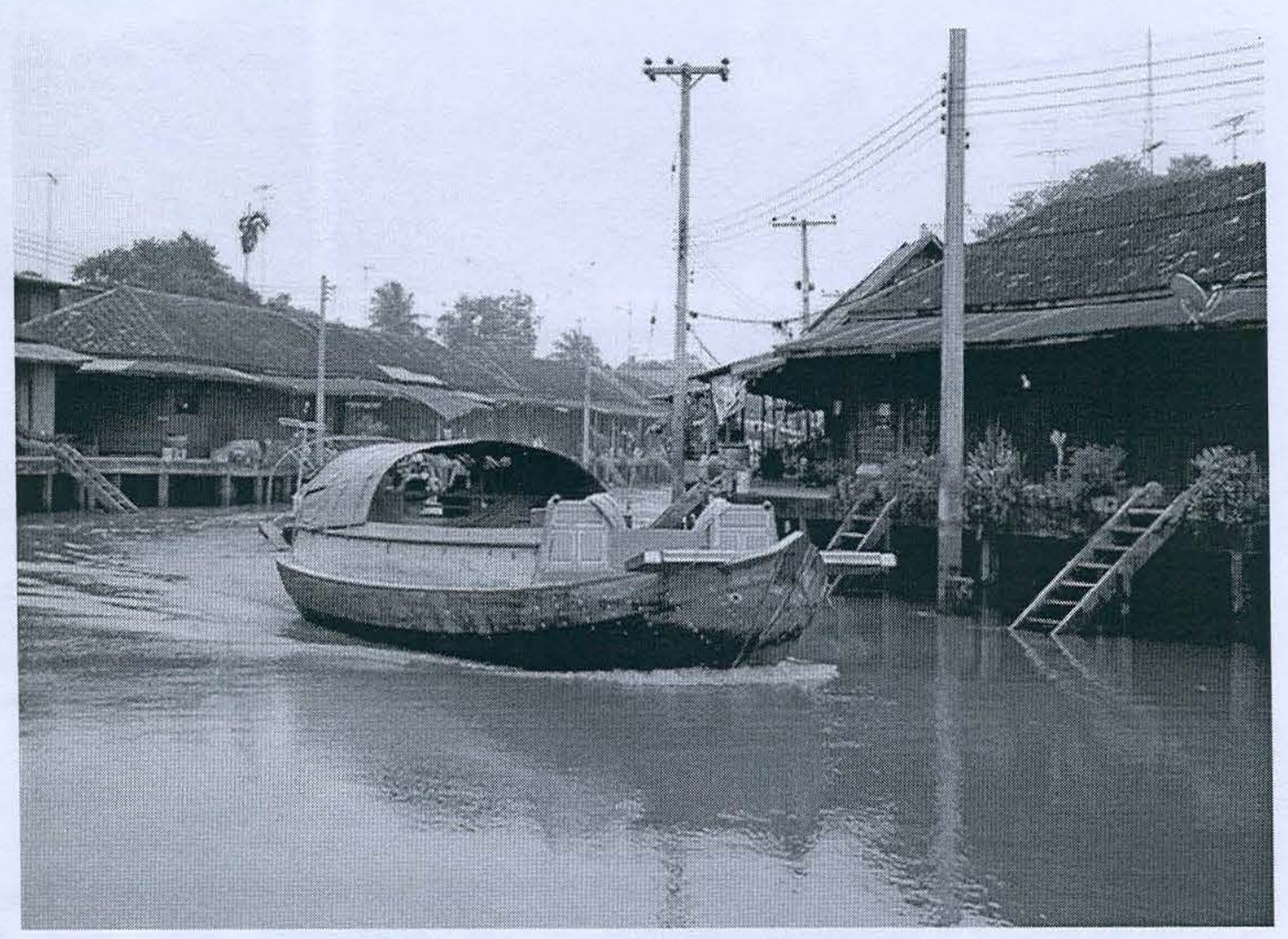

Figure1. The scenery of Amphawa Community

\section{Background and Rationale}

The Amphawa Community stretches along Amphawa Canal and the Mae Klong River in Amphawa District, Samut Songkhram Province, 20 kilometers from the estuary of the Gulf of Thailand and 80 kilometers west of Bangkok. The project also includes another two areas: Krung Rattanakosin and Om-non Canal, the study of which is entrusted respectively to the Faculty of Architecture, Silpakorn University and the Faculty of Architecture, King Mongkut's Institute of Technology. The significant features of the Amphawa community are as follows:

\subsection{Historical value}

Amphawa was once the residence of Rama I and the birth place of King Rama II.

Amphawa was the home town of Somdejphra Amarintramataya, the Queen Consort of King Rama I, and Somdejphra Srisuriyentramataya, the Queen Consort of Rama II. 

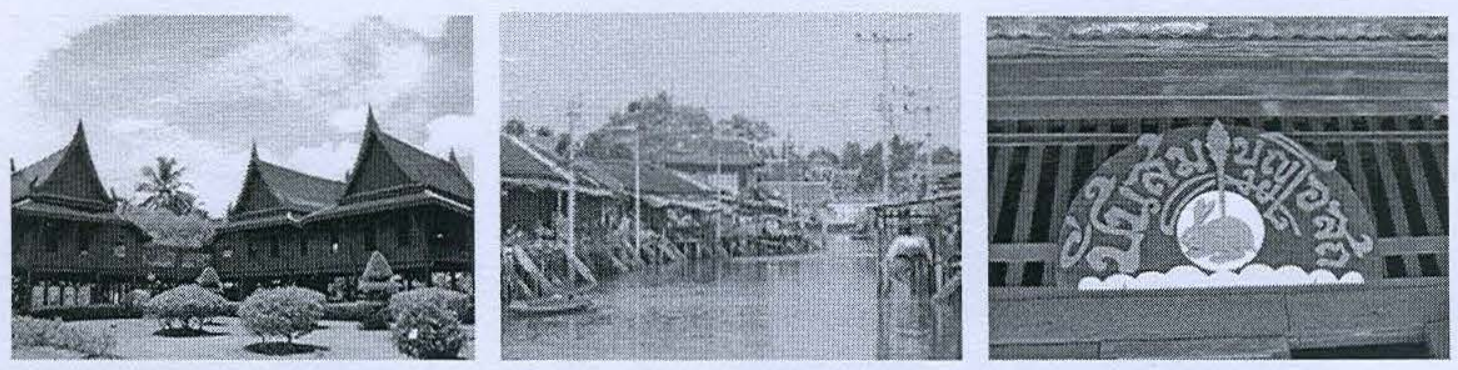

Figure2. Traditional Architecture in Amphawa

King Rama V made two incognito visits to Amphawa. He notably stopped at the house of the then district officer, Khun Wichitsamathakan and the Amphawa Residence of Prince Paribatra Sukhumabhand.

Amphawa (formerly known as Bang Chang Market during the reign of King Prasat Thong in the mid $17^{\text {th }}$ century) has a long history as a water-based settlement since the late Ayudhaya period. The town thrived in terms of trade and farm products (1637-1658).

\subsection{Value in terms of landscape}

There is a network of waterways: river, canals and ditches, linking Amphawa with the Mae Klong River at the estuary of the southern Amphawa Canal which is an extension of the Phee Hlok Canal on the east. It also links with canals, ditches and various irrigation channels which branch out into the inner areas. Besides, Amphawa Canal is situated in an area where fresh and brackish water ebb and flow alternatively in view of its proximity to the mouth of the river.
Traditional orchards with ditches and raised orchard beds can partly be seen nowadays. This reflects local wisdom, making good use of geographical and ecological conditions, as evidenced by a mode of cultivation which is both efficient and not detrimental to the environment. (Figure3.)

\subsection{Architectural Value}

Communities along Amphawa Canal and its neighboring areas boast typical architecture. Unfortunately many houses are in bad repair. They can be grouped as follows: (Figures4, 5)

- Wooden row houses

- Traditional floating houses

- Traditional Thai style houses

- Single traditional local houses in an orchard or a compound

- Residence of wealthy people/old government buildings

- row brick houses

Amphawa Community was awarded "the best conserved community" in 2002 by the Association of Siamese Architects. However, there are no incentives or measures to conserve and restore deteriorated traditional wooden buildings. 

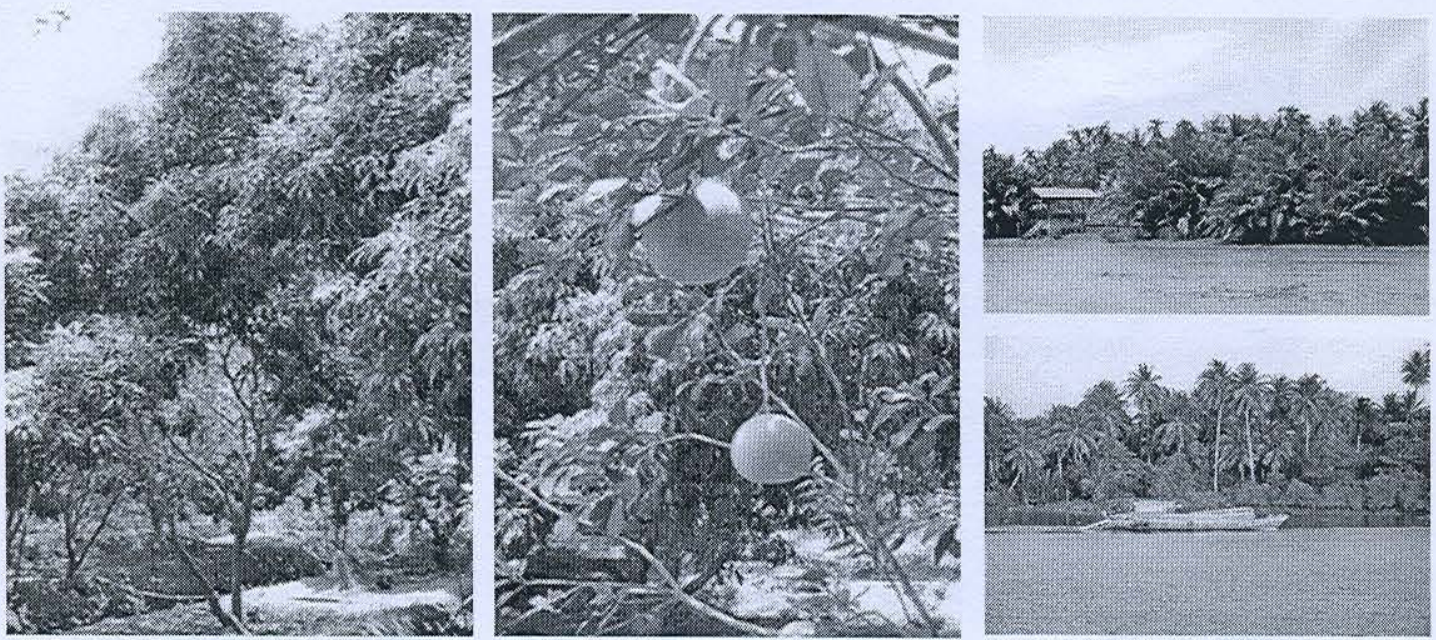

Figure3. Amphawa traditional orchards and landscape
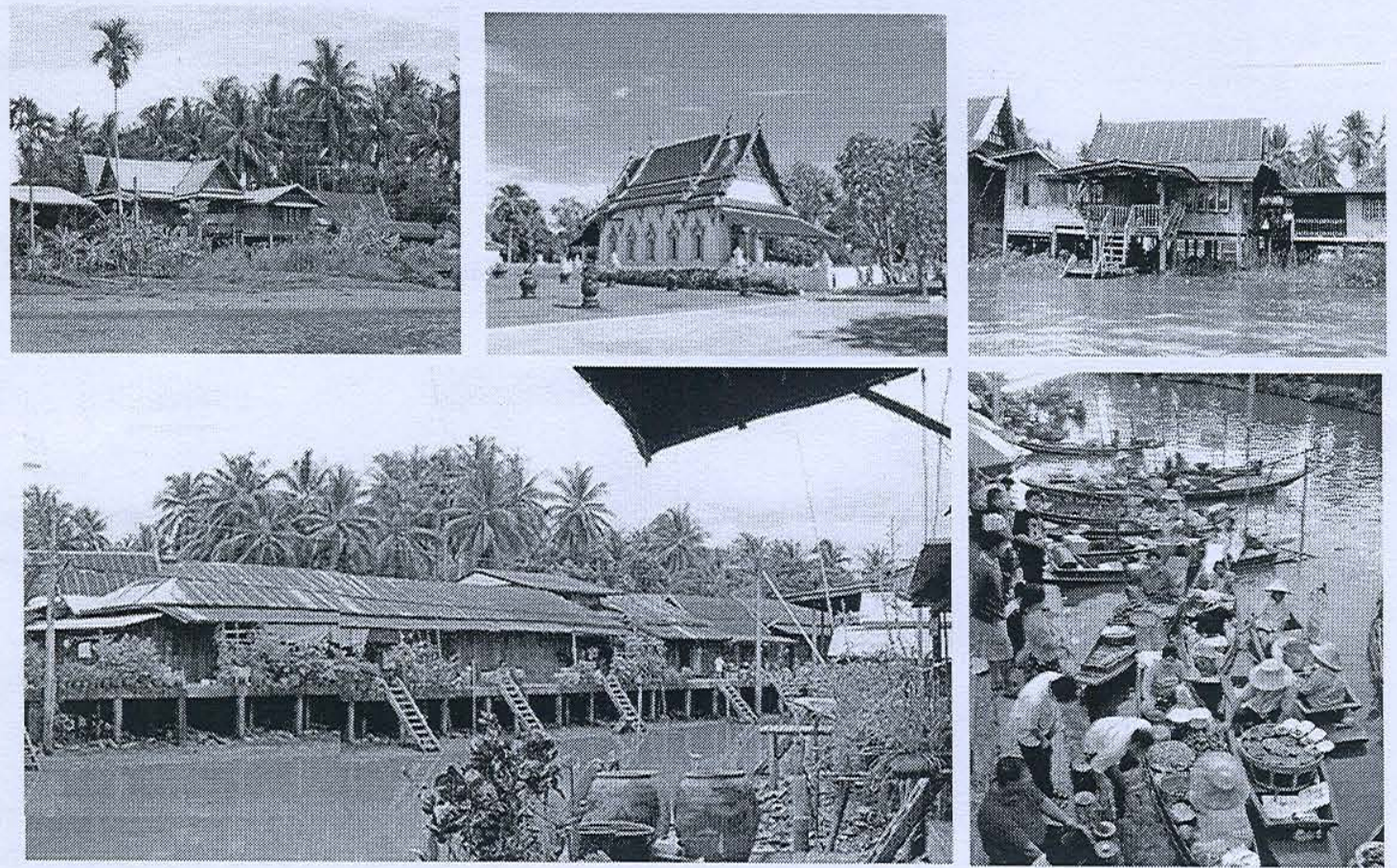

Figure4. Traditional Temples and Thai houses in Amphawa Community and surrounding areas as part of the important cultural heritage of the region 


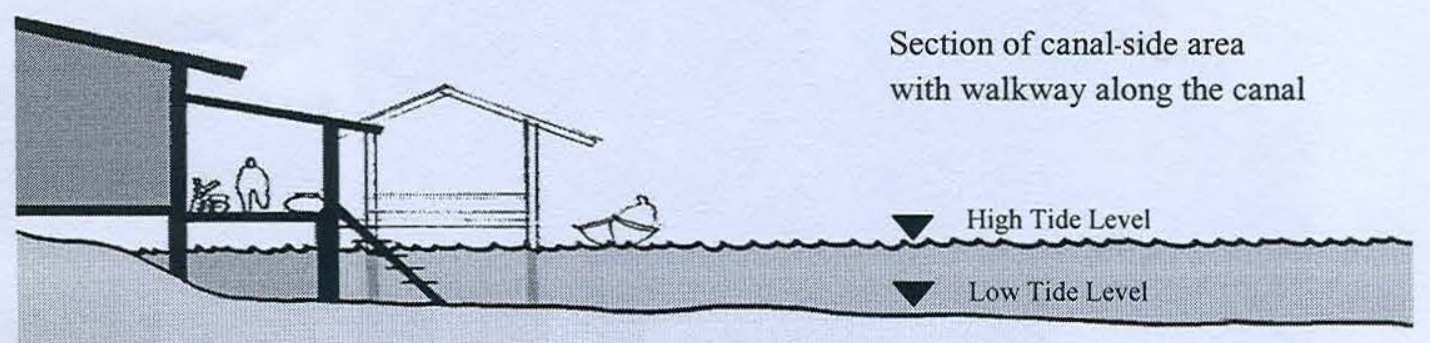

Additional Space and
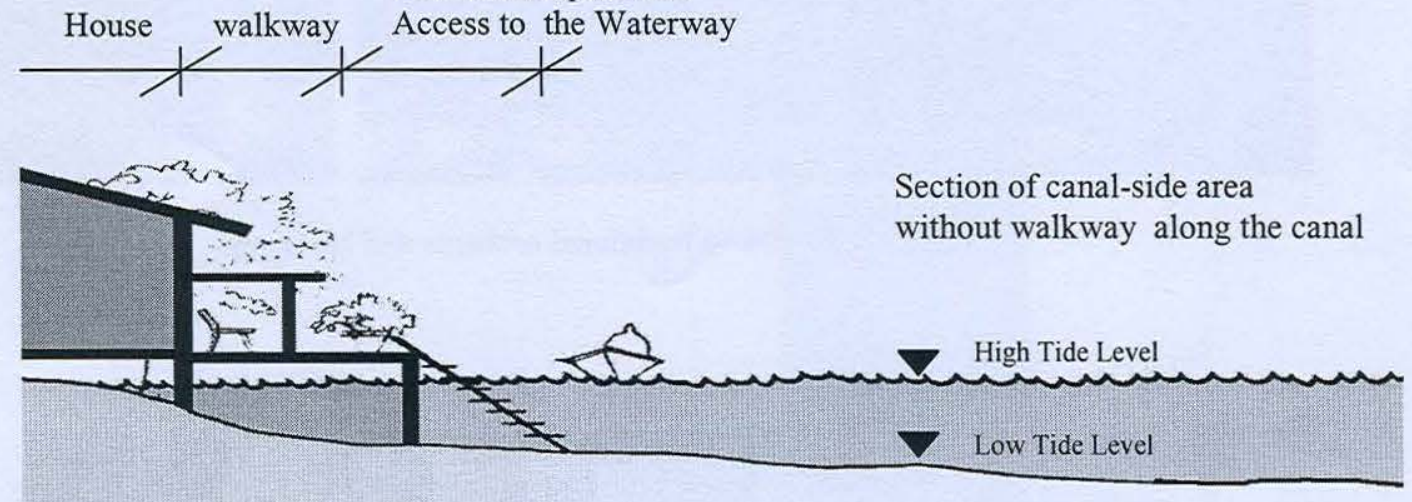

Additional Space and

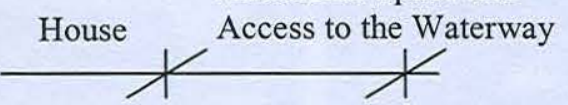

Figure5. Sections of Amphawa Canal Community

\subsection{Economic, Social and Cultural value}

The way of life of a water based community is highly associated with water. Its vestiges can still be seen nowadays as evidence of the use of water from the waterways, communication by water, swimming and bathing in canals.

Local wisdom is shown, for example, by orchard cultivation, coconut sugar making, traditional Thai music, desserts in banana or coconut leaves, and chow-chow.
The area is a traditional trade center for local communities and floating markets are still as dynamic as in the past.

Traditions and customs are as evidenced by Buddhist festivities.

The community of cultural heritage conservation of Amphawa community is as follows: (Figure6.) 
- Conservation of Historic Monuments \& Sites

- Conservation of Natural Environment \& Landscape

- Development Controls \& Guidelines

- Demonstration Projects
- Community Based Tourism Development

- Skill Improvement \& Training Programs

- Income Generation \& Distribution

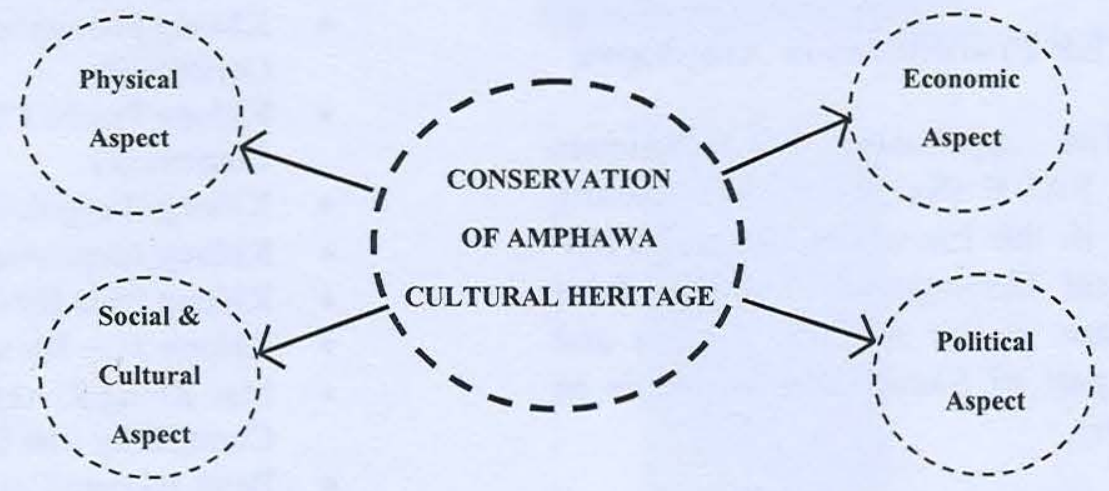

- Conservation of Traditional Way of Life

- Public Participation

- Revitalization of Local Culture \& Traditions

- Conservation Networking

- Awareness Raising

- Community Strengthening

Figure6. Components of cultural heritage conservation of Amphawa community

\section{Objectives}

2.1 To modify and apply the Danish techniques "SAVE" and "CHIP"

2.2 To raise the awareness of local people and organizations.

2.3 To organize demonstration projects for cultural environmental conservation.

2.4 To be a case study for the setting up of a cultural environmental conservation system for Thailand.

\section{Definition}

The term "Cultural Environment" has been defined as follows:

"The environmental or area related to human development from the past to the present, which contains values in the arts, culture, history, archaeology and technology including monuments which should be considered as part of the environment in its entirety". (OEPP)

"Cultural environment is a geographic area reflecting significant historical features, telling the story of man, use of nature, human activities and traditions through history." (Annette SCHOU) 
In summary, none of the assets is required to contain high value aesthetically or monumentally; instead it can be just the area reflecting a traditional lifestyle of normal people or a collective value rather than individual value.

\section{TCEP Procedures in Amphawa}

4.1 The application of techniques called SAVE (Survey of Architecture Value in the Environment) and CHIP (Cultural Heritage in Planning) from Denmark in the Amphawa areas and some part of Samut Songkhram is as follows:

a) To develop a survey form and procedure for cultural heritage environment.

It took time to modify the Danish survey form as the architectural form, material, and uses are very different. The consultants of the 3 sites: Amphawa, Rattanakosin and Om-non, worked together to develop a new survey form to be used for the TCEP project. The procedure was also modified to incorporate more public participation activities. The survey was divided into 2 phases: wide area study for phase 1 (Figure7.) and detailed survey study for phase 2 (Figure8.).

b) To conduct a rapid survey on a provincial level in April - May 2003. There are 20 areas to be recorded regarding significant groups of building sites and major features.
- Khlong Bang Nok Kwak Community

- Khlong Bang Noi Community

- Kwae Om Community

- Khlong Wat Pradu Community

- Khlong Bangkae Community

- Khlong Phongphang Community

- Khlong Pracha Chomchuen Community

- Khlong Bangjak Community

- Khlong Amphawa Community

- Khlong Phee Hlok Community

- Khlong Mae Klong Community

- Mae Klong Riverfront Community (the City)

- Bang Jakreng Community

- Laem Yai Community

- Mae Klong Old Town

- Ban Khao Yisan Community

- Tha Kha Floating Market Community

- Bang Kung Fort Community

- Salt Farm

- Don Hoi Lod

After the rapid survey of architectural value in the environments of 20 sites, Amphawa Community was selected as the site to conduct the CHIP technique for cultural heritage conservation. (Fig.9)

c) To conduct detailed surveys in Amphawa community from October 2003 to May 2004. The in-depth survey to record significant buildings, sites and features. (Figure10.) 


\begin{tabular}{|c|}
\hline $\begin{array}{ll}\text { Identifying : } \\
\text { - } & \text { Local experts } \\
\text { - } & \text { Stakeholders } \\
\text { - } & \text { NGOs } \\
\text { Other sources of } & \text { knowledge }\end{array}$ \\
\hline $\begin{array}{ll}\text { Sources : } \\
=\quad \text { Experts and } \\
& \text { stakeholders } \\
=\quad \text { Maps } \\
=\quad \text { Written history }\end{array}$ \\
\hline
\end{tabular}

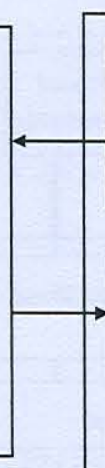

1.1 Characterization of the province
Historical development
Nature and landscape features
Architectural observation
1.2 Overview of historical / socio-
economic / cultural / natural themes
within the province

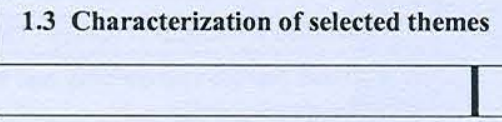

1.4 Identification of areas (potential cultural environment) to be investigated

Mapping areas with one (rare case) or more identified themes or historical subjects

Provincial cultural environment inventory/ report

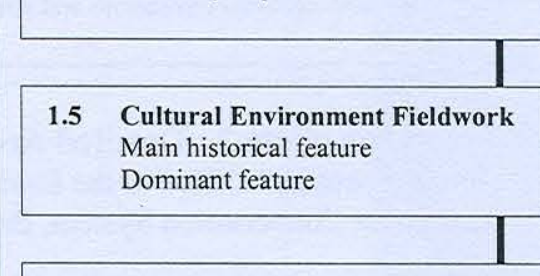

1.6 Analysis of cultural environment Registration of the state of conservation-physical and functional Delimitation of cultural environment

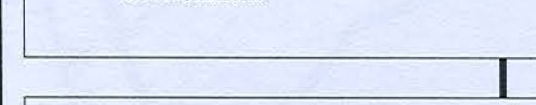

1.7 Valuation and Prioritization of cultural environments

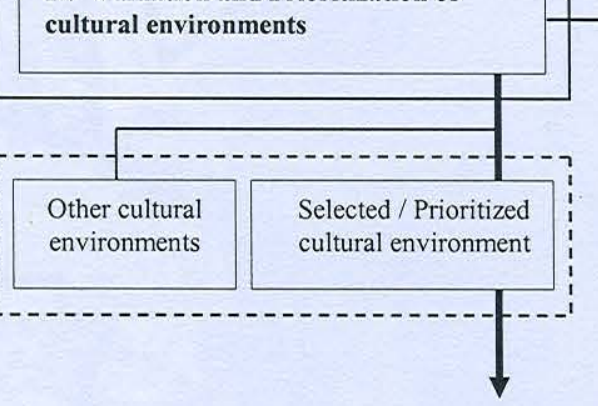

To Phase 2
LFA workshop(s):

To identify problems,

objectives and subject to be addressed
Fieldwork with help from LUNCEC staff and community representatives in the potential cultural environment areas using the community dialogue technique for instance walkthrough-evaluation or image preference

Figure7. Procedure of phase 1: Wide Area study

Source : Danish International Development and Office of the Environment Policy and Planning, Cultural Environment Conversation System, Bangkok 2005 


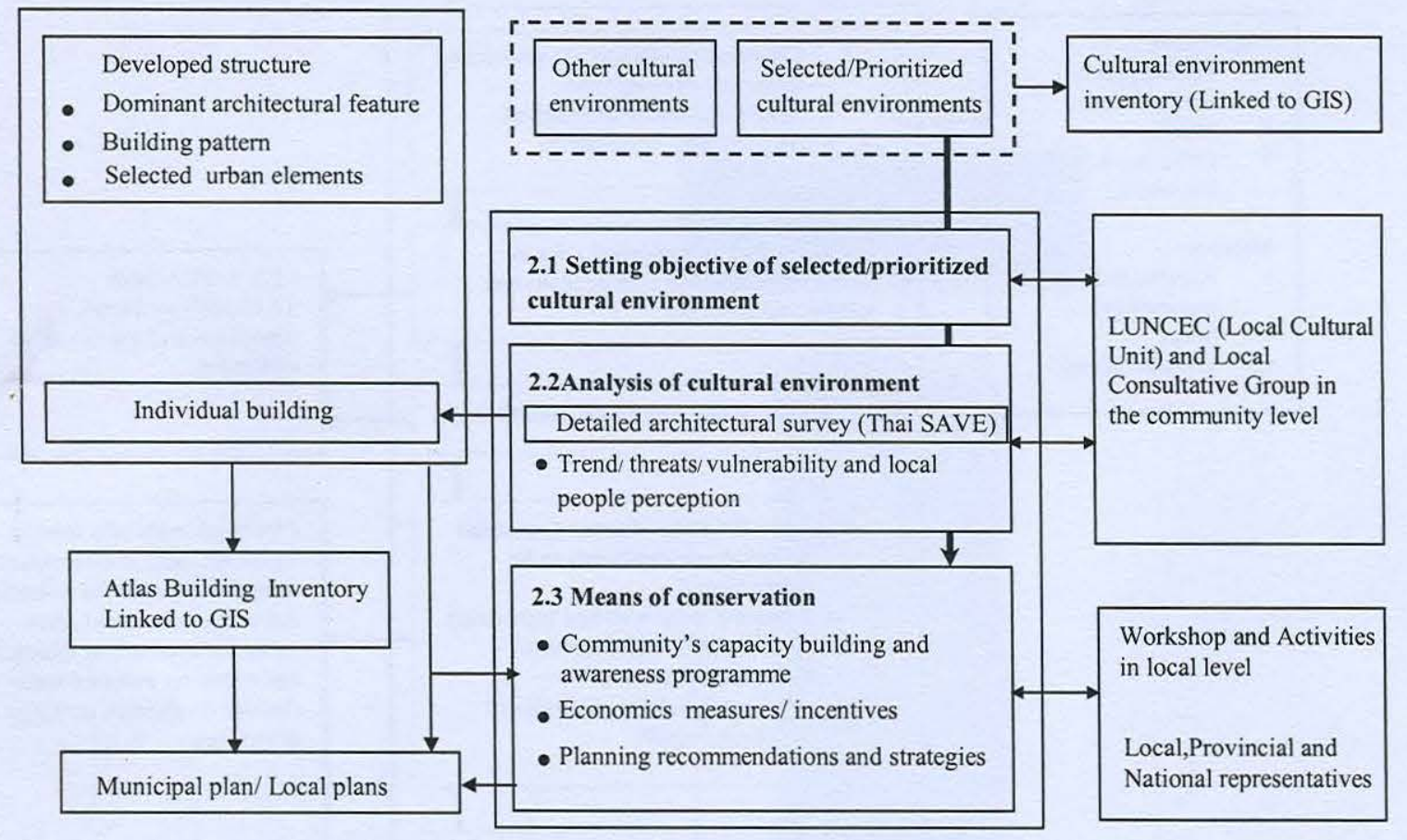

Figure8. Procedure phase 2 : Detailed Area Study

Source : Danish International Development and Office of the Environment Policy and Planning, Cultural Environment Conversation System, Bangkok 2005

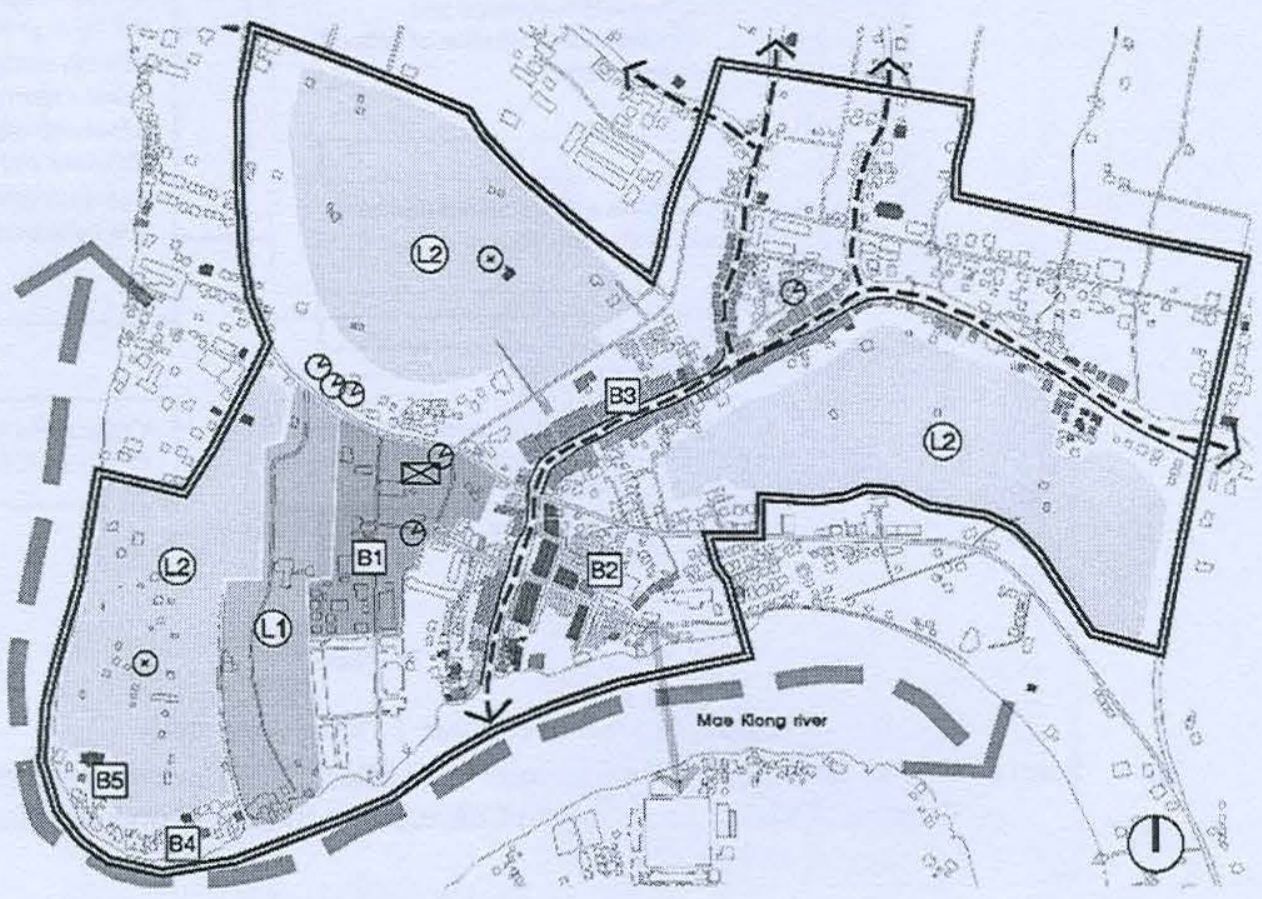

Figure9. Map Produced from the Rapid Survey of Amphawa Community 
Building ornaments data
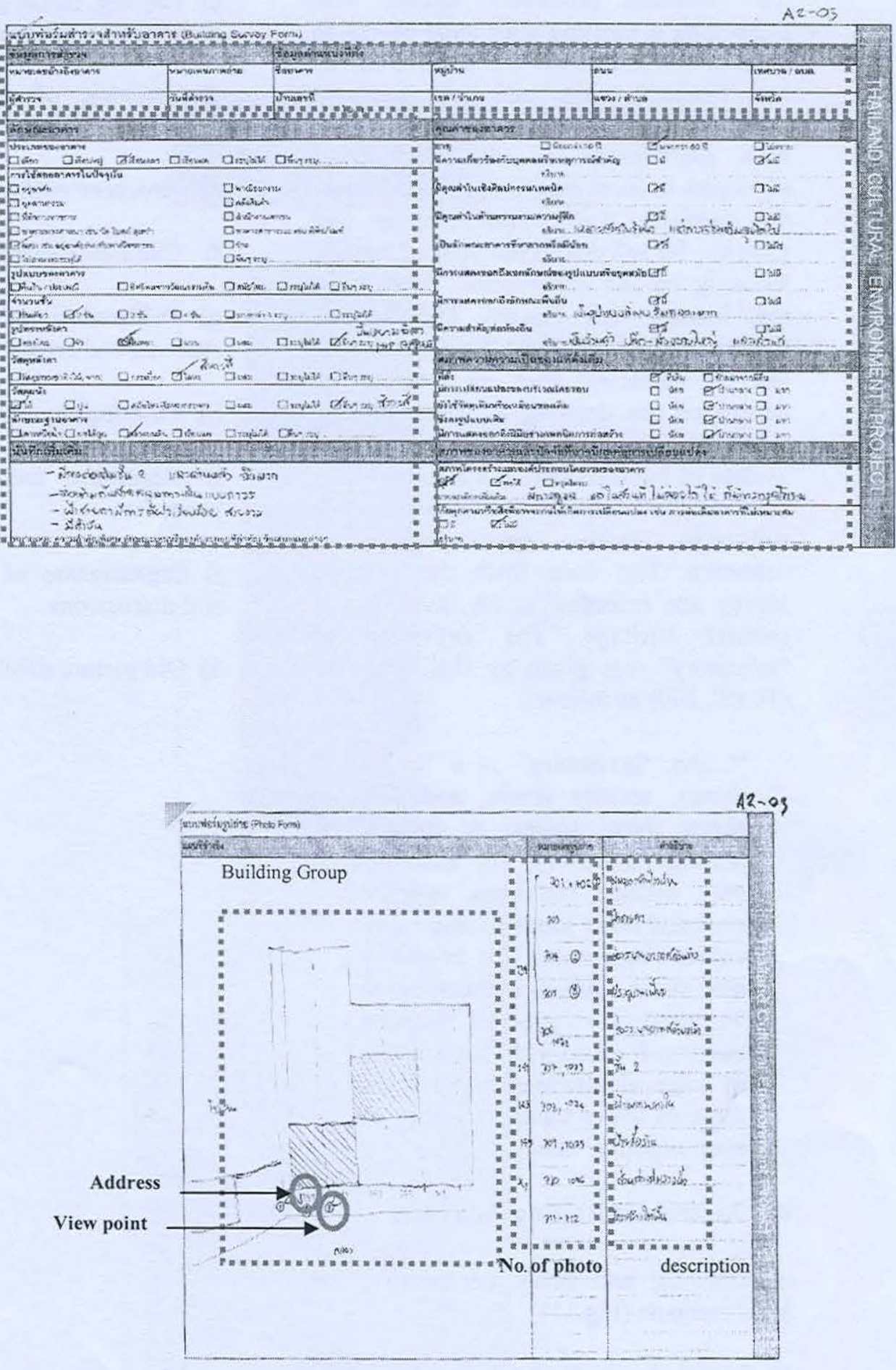

Figure10. Detailed Survey Form for Amphawa Community 
The working procedure started with organizing a meeting with local people to explain the necessity of the detailed survey and measure work, and ask them for cooperation. We introduced our students who participated in the project as surveyors to local people so as to facilitate the measure work, both interior and exterior, for selected prototypes of houses, focusing on the canal-sides. There were row houses, shop houses, Thai houses, former raft houses, local houses, schools, and the municipal hall. As a result, we developed the drawing of the buildings, elevation, floor plans and pictures as well as data of building use. We also collected data on the orchard system, waterways, walkways, public space and road networks. The data from the detailed survey are recorded as an inventory of cultural heritage. The definition of "inventory" was given by Bill Chapman (TCEP, 200) as follows:

"...An 'inventory' is a list of things, usually assets, and data about these assets. A cultural heritage inventory, for example, may include buildings, specific sites and other kinds of historic or cultural resources. The inventory may stand alone as a document to be used for general decision making. It could include resources of high significance as well as those of lower value, no value, or even negative value..."

\subsection{Awareness Raising Activities}

a) Drawing and essay competition for local students (Fig.11)

b) T-shirt screening of Amphawa canal c) Painting Training of Amphawa canal for students by volunteer artists

d) Painting of Amphawa District by volunteer artists

e) Brochure publication

f) Children's camps

g) Publication of greeting cards with students and artists' drawings

h) Paintings by students and artists

i) Receiving international guests and journalists

j) Organization of community meetings and discussions

k) Old picture exhibition 

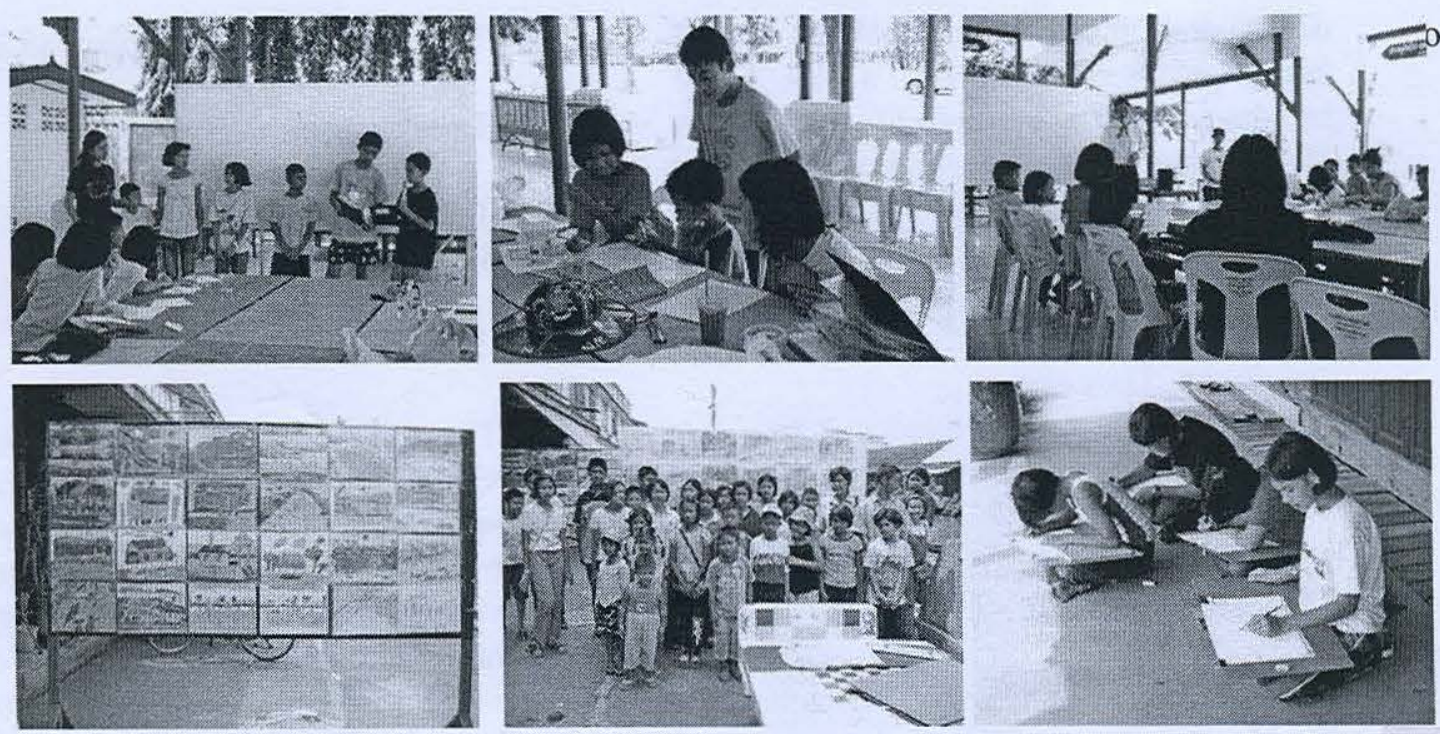

Figure11. Awareness Raising Activity: Cultural Environment Camp for children

Awareness-raising activities have been organised regularly from 2003-2005, targeting administrators, municipal officers and local residents, with emphasis on students. These activities are supported by the municipality, schools, and temples, all of which provide space for proposed activities. In addition, artists interested in cultural heritage also volunteered to give drawing and painting lessons to local students. There are also exhibitions, depicting local scenes and figures in the community life within the past 100 years. This helps revive interest in local history and contributes to collective pride in and attachment to local things, which in turn, will help serve as a strong basis for the development and revitalization of this long-established community along with the conservation of its rare identity. Eventually, it can be said that Amphawa is a small-scale municipality with a population of mostly good-natured local people with a strong sense of cooperation, As a result of the strength of the community, the awareness-raising cultural heritage conservation.

\subsection{Demonstration Projects}

There are several types of buildings under the demonstration projects. The concept of $50 \%$ matching funds between DANIDA and the building owners is applied. The working procedure started in 2004 with a meeting with local people to explain the rules and procedures with the verification of the damage of the building, then they made an assessment of the restoration and budgeting. An agreement was signed between the TCEP project and the building's owner for the building restoration, with $50 \%$ financed by the project. During the start of this activity, the project staff made great efforts to convince local people to participate in the project. The TCEP project rented a house so as to establish a public relations office and a meeting place for interested persons and the project staff. Several public meetings at the Municipal Office were organised with the house-to-house distribution of brochures on the 
demonstration pilot project. After several buildings were restored, a lot more building owners applied to the project after seeing some successful examples. At the end, there were 17 buildings and landscape projects which were restored between September 2004 to March 2005 under the demonstration project in Amphawa. They are:

1) The Municipal Hall (Fig.12)

2) The Four Row houses of the Chaipattana Foundation (Fig.13)

3) A former 100 year-old raft house on the Mae Klong riverside
4) Thai houses along Amphawa Canal

5) Local houses

6) Landscape at the canalside of the floating market

\subsection{Document Production}

1) The output of the rapid survey at a provincial level resulted in the printing of "The Atlas of Cultural Environmental of Samut Songkhram Province". The Atlas served as a reference for conservation planning and activities relating to cultural heritage in Samut Songkhram Province and also as learning material for schools.

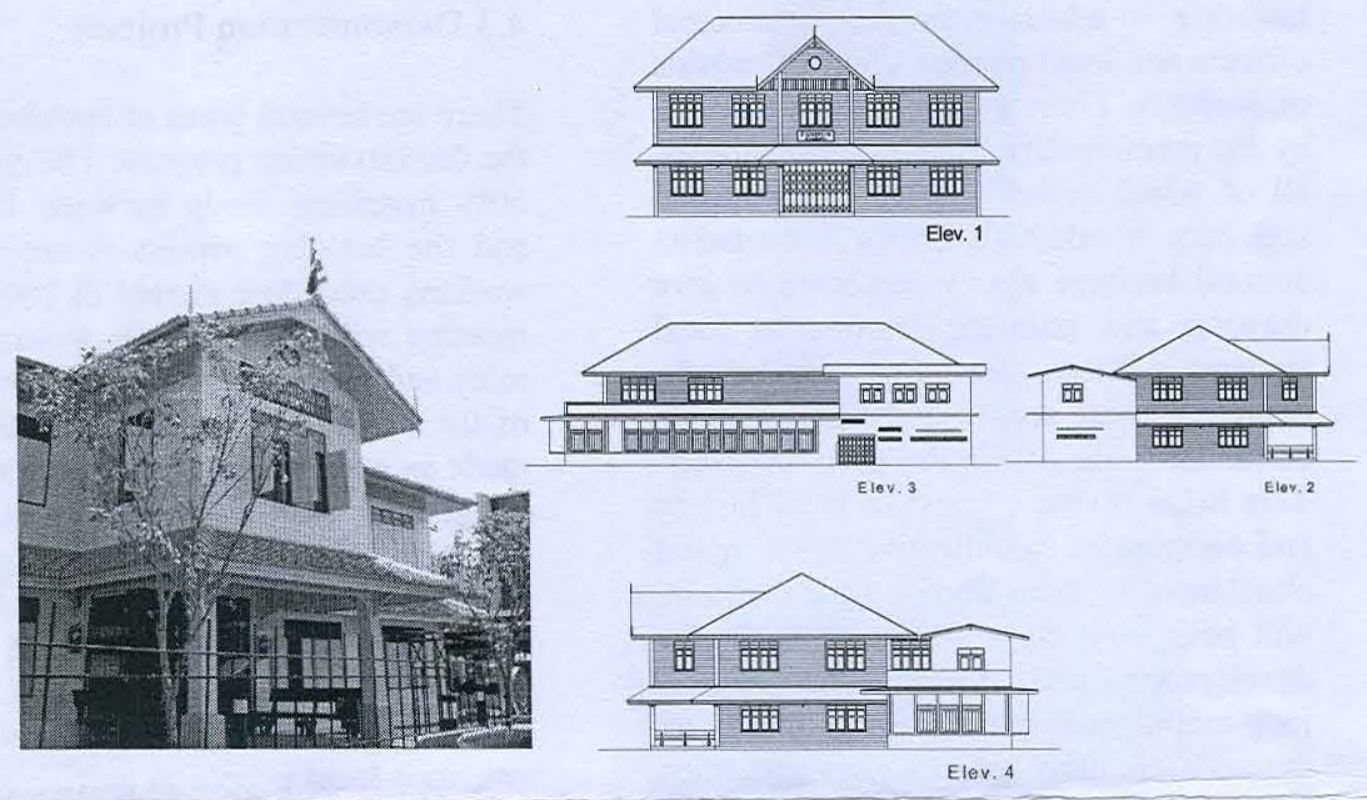

Figure12. Amphawa Municipality Hall 

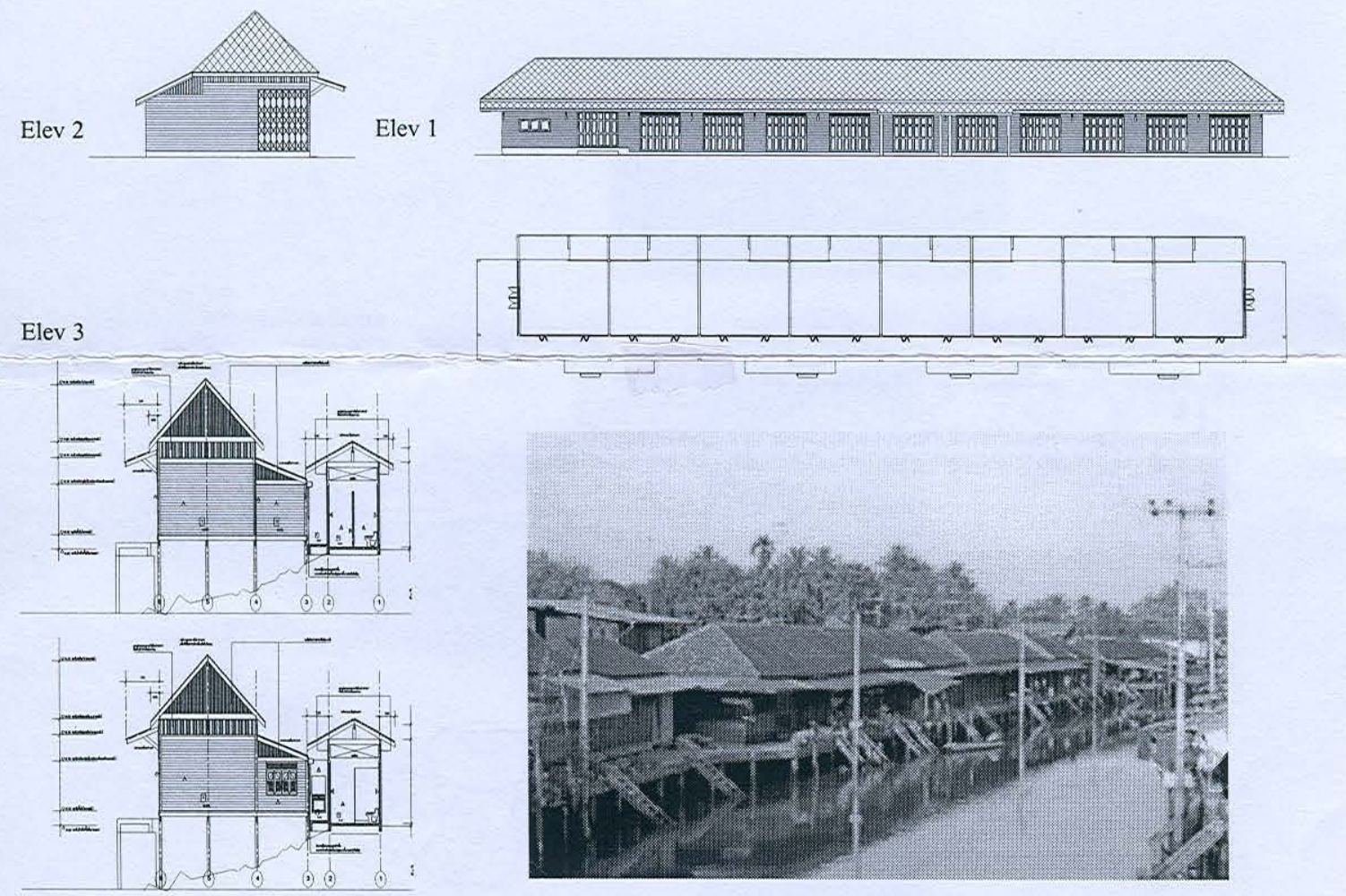

Figure13. Traditional row-houses of the Chaipattana Foundation

2) The output of the detailed survey at a local level resulted in the printing of the "Cultural Heritage Atlas of Amphawa Community." The Atlas can be used as a reference for conservation planning and activities relating to cultural heritage in Amphawa Community. It can also be used as learning material for local schools and awareness raising material. (Fig.14)

3) Tourism Guide Booklet on Amphawa Cultural Heritage; this document is a simplified version of the "Atlas of Cultural of Amphawa Community" for tourism promotion.

\section{Lessons learned and Conclusion}

1) The Amphawa community is related to both water and land in a landscape of orchards with a good ecological system. The conservation of the Amphawa cultural heritage depends on a balance of four factors : physical, economic, sociocultural and administrative conditions. Besides, the master plans of Amphawa and an appropriate building control act will also affect the cultural heritage conservation of Amphawa. 


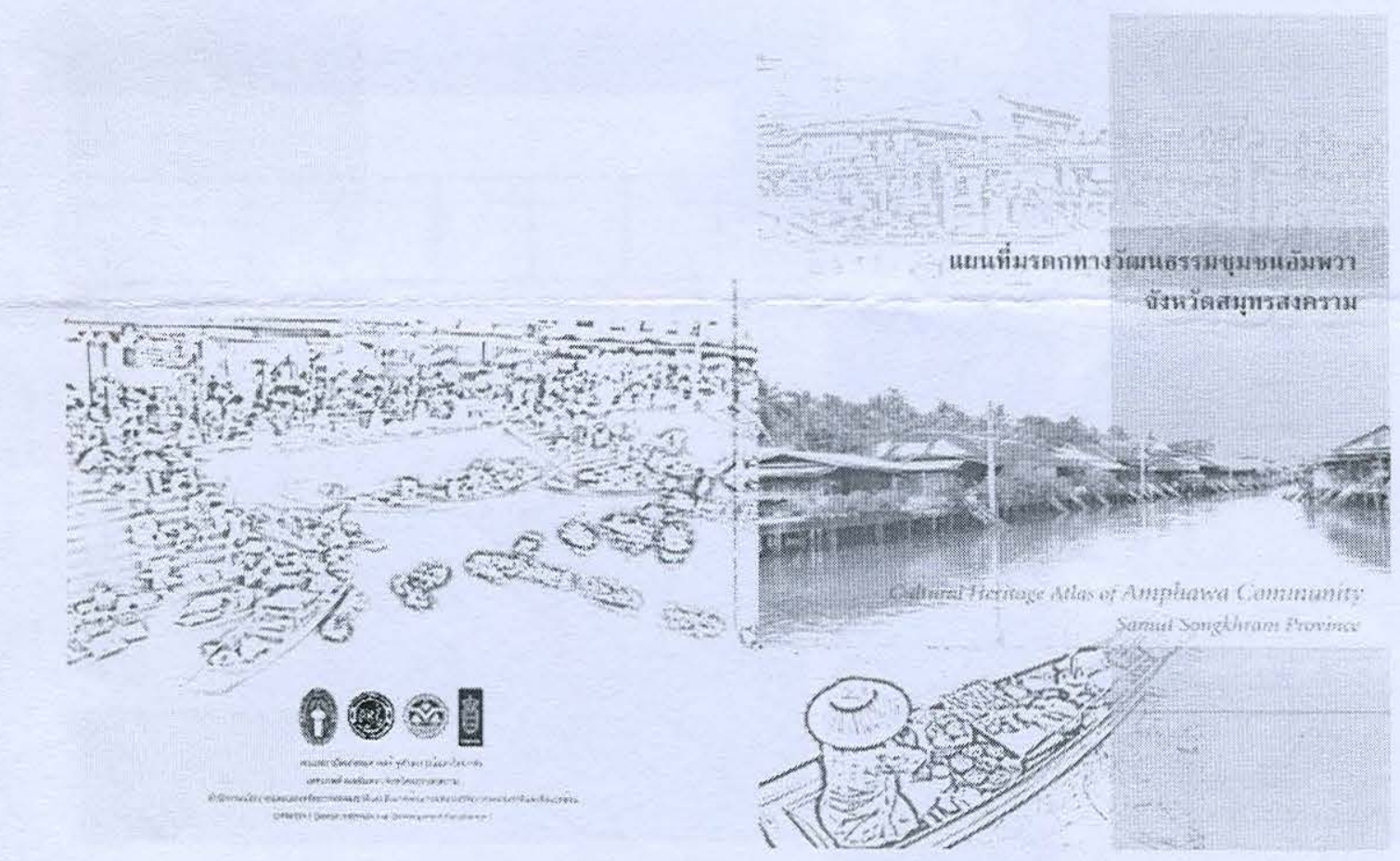

Figure14. The Cover of "Cultural Heritage Atlas of Amphawa Community"

2) Restoration activities also aim at improving the canal environment. A number of restored houses now offer accommodation to tourists.

3) Revitalization of the floating market by the Amphawa Municipality since August 2004 has been instrumental in attracting more tourists to Amphawa Canal. A number of shop houses have been renovated to welcome tourists. However, house and building restoration should be undertaken in a sustainable way in order to build on the present demonstration project undertakens by interested institutes, the private sector and the local community.
4) The Amphawa community offers an excellent case study for other communities which can apply the methods used for the conservation of their cultural environment.

5) Experience gained from the use of the Danish technique "SAVE" (Survey of Architectural Value in the Environment) and "CHIP" (Cultural Heritage in Planning) in the Amphawa community area and the other two areas : the Rattanakosin area and the Om-Non Canal area has led to the "Draft Cultural Environment Conservation System" or "CECS" by the OEPP and will be further tried in other areas. This will help to translate cultural heritage conservation in Thailand into action and to widen its approach to other areas in the future. 


\section{References}

Danish International Development Assistance (DANIDA). 2005. Cultural Environment Atlas of Samut Songkhram. Bangkok. (in Thai)

Danish International Development Assistance (DANIDA). 2005. Cultural Environment conservation system. Bangkok. (in Thai)

Danish International Development Assistance (DANIDA). 2005. Cultural Heritage Atlas of Amphawa Community, Samut Songkhram Province. Bangkok. (in Thai)

N.A., "Draft Cultural Environment Conservation System" (CECS) paper presented at the International Conference on Cultural Environment Conservation : an Integrated Conservation Approach toward Sustainable Development ,9-11 February 2005 at Queen Sirikit Convention Center, Bangkok.

Schou, Annetle. 2000. CHIP : Cultural Heritage in Planning, Identifying Valuable Cultural Environments through Planning. Denmark: Danish Forest and Nature Agency, Ministry of Environment and Energy.

Thailand Cultural Environment Project, Office of the Environmental Policy and Planning, Working Papers, 20032005. 